Article

\title{
Exposure to Bacillus cereus in Water Buffalo Mozzarella Cheese
}

\author{
Angela Michela Immacolata Montone ${ }^{1} \mathbb{D}$, Federico Capuano ${ }^{1}$, Andrea Mancusi ${ }^{1}(\mathbb{D}$, \\ Orlandina Di Maro ${ }^{1}{ }^{1}$, Maria Francesca Peruzy ${ }^{2}$, Yolande Thérèse Rose Proroga ${ }^{1, *}$ \\ and Daniela Cristiano ${ }^{1}$ (D) \\ 1 Department of Food Microbiology, Istituto Zooprofilattico Sperimentale del Mezzogiorno, Via Salute 2, \\ 80055 Portici (NA), Italy; angela.montone@izsmportici.it (A.M.I.M.); \\ federico.capuano@cert.izsmportici.it (F.C.); andrea.mancusi@izsmportici.it (A.M.); \\ orlandina.dimaro@izsmportici.it (O.D.M.); daniela.cristiano@izsmportici.it (D.C.) \\ 2 Department of Veterinary Medicine and Animal Production, University of Naples "Federico II", \\ Via Delpino 1, 80137 Naples, Italy; mariafrancesca.peruzy@unina.it \\ * Correspondence: yolande.proroga@cert.izsmportici.it
}

Received: 14 October 2020; Accepted: 17 December 2020; Published: 19 December 2020

\begin{abstract}
Bacillus cereus is a spoilage bacterium and is recognized as an agent of food poisoning. Two food-borne illnesses are caused by B. cereus: a diarrheal disease, associated with cytotoxin $\mathrm{K}$, hemolysin BL, non-hemolytic enterotoxin and enterotoxin FM, and an emetic syndrome, associated with the cereulide toxin. Owing to the heat resistance of B. cereus and its ability to grow in milk, this organism should be considered potentially hazardous in dairy products. The present study assessed the risk of $B$. cereus poisoning due to the consumption of water buffalo mozzarella cheese. A total of 340 samples were analyzed to determine B. cereus counts (ISO 7932:2005); isolates underwent molecular characterization to detect the presence of genes encoding toxins. Eighty-nine $(26.1 \%)$ samples harbored B. cereus strains, with values ranging from $2.2 \times 10^{2}$ to $2.6 \times 10^{6} \mathrm{CFU} / \mathrm{g}$. Isolates showed eight different molecular profiles, and some displayed virulence characteristics. Bacterial counts and the toxin profiles of isolates were evaluated both separately and jointly to assess the risk of enteritis due to B. cereus following the consumption of buffalo mozzarella cheese. In conclusion, the results of the present study showed that the risk of poisoning by B. cereus following the consumption of this cheese was moderate.
\end{abstract}

Keywords: Bacillus cereus; water buffalo mozzarella cheese; risk of poisoning; toxinotype

\section{Introduction}

The Bacillus cereus group, also known as B. cereus sensu lato (s.l.), comprises several closely related species of Gram-positive aerobic spore-forming bacteria, which are widely distributed in nature. Within the group, B. cereus sensu stricto (s.s.), B. cereus, B. thuringiensis, B. anthracis, B. mycoides, B. pseudomycoides, $B$. weihenstephanensis, $B$. cytotoxicus and $B$. toyonensis are the most important members [1-4]. The majority of these species are usually harmless. However, some species, especially B. cereus s.s., can cause food-borne illness in humans. B. cereus s.s., according to the combination of genes harbored, and therefore to the toxins produced, can cause two different types of food poisoning: a diarrheal syndrome and an emetic syndrome [5].

The B. cereus diarrheal syndrome is caused by several heat-labile and gastro-labile toxins, including hemolysin BL (HBL), non-hemolytic enterotoxin (NHE), cytotoxin K (CytK) and enterotoxin FM (EntFM) [6-10], which are produced during vegetative bacterial growth in the small intestine. By contrast, the emetic syndrome is caused by the production of the heat-stable and gastro-stable peptide toxin cereulide (Ces) [11], which is produced in foodstuffs. 
Several other putative enterotoxins (hemolysin II, hemolysin III, cereolysin $\mathrm{AB}$, cereolysin $\mathrm{O}$, and enterotoxin T) that might also contribute to virulence have been described [12]. Moreover, it has been reported that genes encoding toxins may characterize species other than B. cereus sensu stricto $[13,14]$. Therefore, other species comprising the B. cereus group may also be pathogenic for human beings. Detection of the genes, and also of the toxins, provides an indication of the toxicity of a strain, but is not sufficient to fully distinguish the virulence profiles of different $B$. cereus strains [12]. Thus, to assess virulence correctly, other factors (e.g., the infective dose) should be included in the analysis [11].

In the literature, a value of $10^{5}-10^{8}$ cells or spores per gram is generally considered to be the infective dose for $B$. cereus $[15,16]$ but lower bacterial counts have also been reported in cases of human poisoning; therefore, no food containing more than $10^{3} \mathrm{CFU} / \mathrm{g}$ can be considered completely safe for consumption [17].

Bacillus spp.related outbreaks in Europe have increased significantly. However, in Italy, notifications and reports of B. cereus poisoning are scarce [18-20]. Therefore, the true impact of B. cereus poisoning on health is still not known.

Although most human cases have been associated with the consumption of rice and vegetables, almost all kinds of food may be involved in food-borne B. cereus poisoning [17,21,22]. Moreover, B. cereus is a frequent contaminant of raw milk and, owing to the extreme resistance of endospores to milk pasteurization, cheese-processing heat treatments and fermentation, it has also been frequently reported in dairy products $[8,23]$.

Water buffalo mozzarella cheese (WBMC) is one of southern Italy's most popular "pasta filata" cheeses, and is globally commercialized, usually at refrigeration temperature [24]. During the manufacture of WBMC, the curd is stretched in hot water (about $90^{\circ} \mathrm{C}$ ), which reduces the microbial load; nevertheless, it has been demonstrated that Salmonella typhimurium and Listeria monocytogenes can survive $[25,26]$. This suggests that the survival of spore-forming bacteria is even more likely. Although studies on the contamination of cheeses by B. cereus have been conducted [27-29], little is known about its presence in WBMC. Therefore, the aims of this study were: (i) to study the occurrence of B. cereus s.l. in WBMC; (ii) to evaluate the presence of nine genes encoding toxins in the isolated strains; and (iii) to assess the risk of $B$. cereus poisoning due to the consumption of water buffalo mozzarella cheese through a combined approach based on the evaluation of bacterial contamination and analysis of the virulence profile.

\section{Materials and Methods}

\subsection{Sampling}

From January 2015 to October 2017, a total of 340 WBMC samples, with a shelf life no longer than seven days, were aseptically collected at different dairies in the Campania region of southern Italy. Samples were transported at $4{ }^{\circ} \mathrm{C}$ to the laboratory and immediately analyzed.

\subsection{Bacterial Counting and Identification}

Microbiological assays were performed in accordance with the ISO 7932:2005 method. In brief, $10 \mathrm{~g}$ of each sample and $90 \mathrm{~mL}(1: 10(w / w))$ of sterilized buffered peptone water (BPW; Oxoid, UK) were placed in a sterile stomacher bag and homogenized for $3 \mathrm{~min}$ at $230 \mathrm{rpm}$ using a peristaltic homogenizer (BagMixer ${ }^{\circledR} 400$ P, Interscience, Saint Nom la Bretèche, France). Subsequently, the homogenized samples were submitted to ten-fold serial dilutions in BPW followed by spread-plating on Mannitol Egg Yolk Polymyxin Agar (MYP; Thermo Scientific, Waltham, MA, USA) and incubated at $30^{\circ} \mathrm{C}$ for $48 \mathrm{~h}$. Suspected colonies were counted and randomly picked out (up to five isolates) for the evaluation of hemolytic activity on Trypticase Soy Agar 5\% sheep blood (Biolife, Monza, Italy). Confirmatory biochemical assessment of the isolates was carried out by means of a Vitek device (bioMerieux, France), according to the manufacturer's instructions. Harvested colonies were then subcultured in nutrient broth (Biolife, Monza, Italy), and incubated at $30{ }^{\circ} \mathrm{C}$ for $4 \mathrm{~h}$ for subsequent real-time PCR. 


\subsection{Estimation of the Probability of Growth}

To estimate $B$. cereus growth rates at three different temperatures $\left(15,18\right.$ and $\left.22{ }^{\circ} \mathrm{C}\right)$, the ComBase Predictor software (www.combase.cc) was used. The parameters considered ( $\mathrm{pH}=5.7$ and $\mathrm{a}_{\mathrm{w}}=0.997$ ) were those described by [30]. The starting counts used in the predictions were 2 and $3 \log \mathrm{CFU} / \mathrm{g}$, while for the physiological state, the input parameter (0.00027) contained in the ComBase Predictor was chosen.

\subsection{Gene Detection in B. cereus Strains}

One milliliter of each broth culture was transferred into a clean microcentrifuge tube and centrifuged for $3 \mathrm{~min}$ at $4000 \times \mathrm{g}$. Subsequently, the supernatant was discarded, and the pellet was washed twice with $500 \mu \mathrm{L}$ of sterile DNase-free water. After a second centrifugation, the supernatant was discarded, and the pellet was resuspended in $100 \mu \mathrm{L}$ of Milli-Q. The suspension was then incubated at $98 \pm 1{ }^{\circ} \mathrm{C}$ for $10 \mathrm{~min}$ and centrifuged at $10^{4} \times g$ for $5 \mathrm{~min}$.; $2.5 \mu \mathrm{L}$ of the DNA extracted was used as a template for producing amplicons in a conventional PCR reaction, which was performed in a final volume of $25 \mu \mathrm{L}$ using the GoTaq Green Master Mix (Promega, Madison, WI, USA). Nine genes were investigated: $h b l A, h b l D$ and $h b l C$, encoding HDL enterotoxin; nhe $A, n h e B$ and $n h e C$, encoding NHE; cyfK, encoding CytK; entFM, encoding EntFM; and ces, encoding Ces. The primers used in the present study are listed in Table 1.

Table 1. Primer sequences utilized to detect nine genes encoding five toxins in B. cereus isolates.

\begin{tabular}{|c|c|c|c|c|}
\hline Toxin & $\begin{array}{l}\text { Target } \\
\text { Gene }\end{array}$ & $\begin{array}{c}\text { Primer Sequence } \\
\qquad\left(5^{\prime}-3^{\prime}\right)\end{array}$ & Product Size (bp) & Reference \\
\hline \multirow{6}{*}{ HBL } & \multirow{2}{*}{$h b l \mathrm{~A}$} & F-GCAAAATCTATGAATGCCTA & \multirow{2}{*}{884} & \multirow{16}{*}{ [31] } \\
\hline & & R-GCATCTTGTTCGTAATGTTTT & & \\
\hline & \multirow{2}{*}{$h b l \mathrm{D}$} & F-GAAACAGGGTCTCATATTCT & \multirow{2}{*}{1018} & \\
\hline & & R-CTGCATCTTTATGAATATCA & & \\
\hline & \multirow{2}{*}{$h b l C$} & F-CCTATCAATACTCTCGCAA & \multirow{2}{*}{695} & \\
\hline & & R-TTTCCTTTGTTATACGCTGC & & \\
\hline \multirow{6}{*}{ NHE } & \multirow{2}{*}{ nheA } & F-TAAGGAGGGGCAAACAGAAG & \multirow{2}{*}{759} & \\
\hline & & R-TGAATGCGAAGAGCTGCTTC & & \\
\hline & \multirow{2}{*}{ nheB } & F-CAAGCTCCAGTTCATGCGG & \multirow{2}{*}{935} & \\
\hline & & R-GATCCCATTGTGTACCATTG & & \\
\hline & \multirow{2}{*}{ nheC } & F-ACATCCTTTTGCAGCAGAAC & \multirow{2}{*}{618} & \\
\hline & & R-CCACCAGCAATGACCATATC & & \\
\hline \multirow{2}{*}{ CytK } & \multirow{2}{*}{ cytK } & F-CGACGTCACAAGTTGTAACA & \multirow{2}{*}{565} & \\
\hline & & R-CGTGTGTAAATACCCCAGTT & & \\
\hline \multirow{2}{*}{ EntFM } & \multirow{2}{*}{ entFM } & F-GTTCGTTCAGGTGCTGGTTAC & \multirow{2}{*}{486} & \\
\hline & & R-AGCTGGGCCTGTACGTACTT & & \\
\hline \multirow{2}{*}{ Ces } & \multirow{2}{*}{ ces } & F-GGTGACACATTATCATATAAGGTG & \multirow{2}{*}{1271} & \multirow{2}{*}{ [32] } \\
\hline & & R-GTAAGCGAACCTGTCTGTAACAACA & & \\
\hline
\end{tabular}

The PCR products were highlighted by means of a QIAxcel Advanced device (Qiagen). Bacillus cereus ATCC 11778 PK/5, Bacillus cereus ATCC 14579, and B. thuringiensis subsp. aizawaii strain GC-91, were used as controls. For confirmatory purposes, the amplicons obtained for cereulide detection were sequenced and compared with the sequences in Gene Bank. 


\subsection{Exposure Assessment}

To estimate the probability that buffalo mozzarella consumers will suffer an adverse effect because of $B$. cereus contamination, the exposure assessment was performed in the final phase of the food chain, i.e., at retail outlets. The bacterial count and the virulence profile (toxinotype) of the isolates were evaluated both separately and jointly. Taking into account the estimated average annual consumption of mozzarella and the percentage of samples contaminated (prevalence), the exposure risk was calculated as:

$$
\mathrm{R}_{\mathrm{xp}}=\left(\mathrm{M}_{\mathrm{C}} / 100\right) \times \mathrm{R}_{\mathrm{C}}
$$

where:

$\mathrm{R}_{\mathrm{xp}}=$ exposure risk;

$\mathrm{M}_{\mathrm{C}}=$ mozzarella per capita average consumption;

$\mathrm{R}_{\mathrm{C}}=$ risk classes (prevalence).

\section{Results}

\subsection{Bacterial Counts}

B. cereus was recovered in 89 of the 340 samples $(26.2 \%)$, with a bacterial count ranging from $2.2 \times 10^{2}$ to $3.6 \times 10^{6} \mathrm{CFU} / \mathrm{g}$ (Table 2). Positive samples were stratified into five classes on the basis of their B. cereus count (Table 2). Overall, 59 of the 89 positive strains $(66.3 \%)$ showed a level of contamination $<10^{3} \mathrm{CFU} / \mathrm{g}$. The other positive strains showed higher levels of contamination $\left(10^{3}-10^{4}\right.$ $\left.(20.2 \%) ; 10^{4}-10^{5}(6.7 \%) ; 10^{5}-10^{6}(3.4 \%) ;>10^{6}(3.4 \%)\right)$.

Table 2. B. cereus counts in 340 water buffalo mozzarella cheese (WBMC) samples and haplotypes of isolated strains. Positive samples were stratified into five classes based on the B. cereus count.

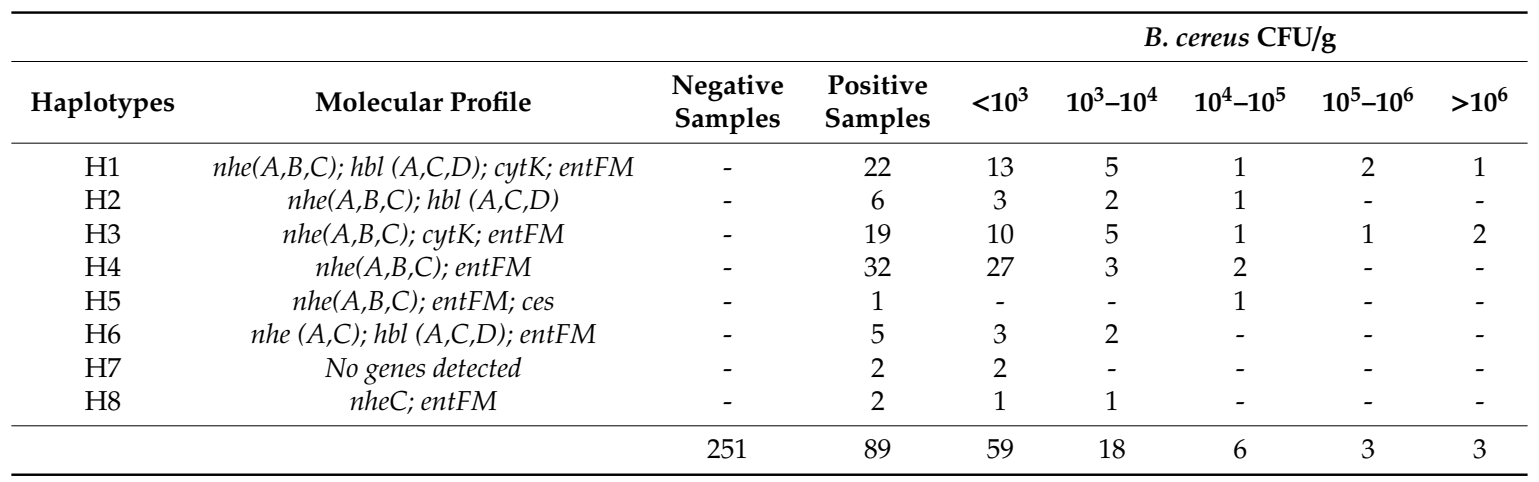

Specifically, $6(1.8 \%), 24(7.1 \%)$ and $59(17.3 \%)$ samples showed levels of contamination $>10^{5}$, between $10^{5}$ and $10^{3}$, and $<10^{3} \mathrm{CFU} / \mathrm{g}$, respectively.

\subsection{Estimation of the Probability of Growth}

B. cereus in samples with initial contamination levels of $2 \log \mathrm{CFU} / \mathrm{g}$ and $3 \log \mathrm{CFU} / \mathrm{g}$, under the conditions considered (storage temperature $\left(15^{\circ} \mathrm{C} ; 18^{\circ} \mathrm{C} ; 22^{\circ} \mathrm{C}\right), \mathrm{pH}(5.7)$ and aw $\left.(0.997)\right)$, reached levels of $\geq 5 \log \mathrm{CFU} / \mathrm{g}$ in 21 to $53 \mathrm{~h}$ (Table 3). Specifically, in samples with an initial contamination level of $2 \log \mathrm{CFU} / \mathrm{g}$, B. cereus reached levels of $\geq 5 \log \mathrm{CFU} / \mathrm{g}$ in around 25, 41 and $63 \mathrm{~h}$ at 22,18 and $15^{\circ} \mathrm{C}$, respectively. In those with an initial contamination level of $3 \log \mathrm{CFU} / \mathrm{g}, \mathrm{B}$. cereus reached levels of $\geq 5 \log \mathrm{CFU} / \mathrm{g}$ in around 21,35 and $53 \mathrm{~h}$ at 22,18 and $15^{\circ} \mathrm{C}$, respectively. Moreover, regarding microbial growth, the maximum growth rate $(\log \cdot \mathrm{con} c / \mathrm{h})$, the doubling time (hours), the maximum population density (MPD; log CFU/g) and the lag time (hours) were estimated (Table S1). On comparing the three temperatures, at $22{ }^{\circ} \mathrm{C} \mathrm{B}$. cereus showed the highest growth rate per hour $(0.268 \mathrm{log} \cdot \mathrm{conc} / \mathrm{h})$, the shortest doubling time $(1.125 \mathrm{~h})$ and the shortest lag time $(13.29 \mathrm{~h})$. 
Table 3. Rate of growth of B. cereus from initial contamination levels of $2 \log$ CFU/g and $3 \log$ CFU/g in water buffalo mozzarella cheese ( $\mathrm{pH} 5.7$ and $\mathrm{a}_{\mathrm{w}}$ 0.997) at three temperatures $\left(15,18\right.$ and $\left.22{ }^{\circ} \mathrm{C}\right)$ calculated by ComBase Predictor software (www.combase.cc).

\begin{tabular}{ccccccc}
\hline \multicolumn{5}{c}{ Concentration (Log Cells/g) at Different Temperatures } \\
\hline \multirow{2}{*}{ Time } & \multicolumn{2}{c}{$\mathbf{2 2}{ }^{\circ} \mathbf{C}$} & \multicolumn{2}{c}{$\mathbf{1 8}{ }^{\circ} \mathbf{C}$} & \multicolumn{2}{c}{$\mathbf{1 5}{ }^{\circ} \mathbf{C}$} \\
\cline { 2 - 7 } (Hours) & Log CFU/g & Log CFU/g & Log CFU/g & Log CFU/g & Log CFU/g & Log CFU/g \\
\hline 0.00 & 3.00 & 2.00 & 3.00 & 2.00 & 3.00 & 2.00 \\
20.62 & 5.01 & 4.01 & 3.2 & 2.2 & 3.01 & 2.02 \\
24.60 & 6.06 & 5.07 & 3.55 & 2.55 & 3.04 & 2.04 \\
34.73 & 7.58 & 7.4 & 5.03 & 4.04 & 3.35 & 2.35 \\
40.88 & 7.6 & 7.6 & 6.01 & 5.02 & 3.81 & 2.81 \\
53.19 & 7.6 & 7.6 & 7.46 & 6.9 & 5.02 & 4.03 \\
62.59 & 7.6 & 7.6 & 7.6 & 7.56 & 6.00 & 5.01 \\
\hline
\end{tabular}

\subsection{Gene Detection in B. cereus Strains}

A total of 89 strains were analyzed for gene detection. The most common genes in B. cereus strains were entFM and nheC (97.7\% each), followed by nheA (95.5\%), nheB (89.9\%), cytK (46.1\%), hblA, hblC, $h b l D(37.1 \%$ each) and ces (1.1\%) (Table 4$)$.

Table 4. Number (No.) and percentage (\%) of B-cereus strains containing nine genes $(h b l A, h b l C, h b l D$, nhe A, nheB, nheC, cytK, entFM and ces) encoding five toxins (HBL, NHE, CytK, EntFM and Ces).

\begin{tabular}{|c|c|c|c|c|c|c|c|c|c|}
\hline & \multicolumn{9}{|c|}{ Gene Target } \\
\hline & & $h b l$ & & & nhe & & cytK & entFM & ces \\
\hline & $A$ & $C$ & $D$ & $A$ & $B$ & $C$ & & & \\
\hline No. & 33 & 33 & 33 & 85 & 80 & 87 & 41 & 87 & 1 \\
\hline$\%$ & 37.1 & 37.1 & 37.1 & 95.5 & 89.9 & 97.7 & 46.1 & 97.7 & 1.1 \\
\hline
\end{tabular}

The three genes $(h b l A, h b l C, h b l D)$ coding for the trimeric HBL toxin were always simultaneously detected. The concomitant presence of the three genes coding for the NHE toxin was observed in 80 isolates; five isolates were positive for both the nhe $A$ and nhe $C$ genes, and two were positive exclusively for the $n$ he $C$ gene. Only one isolate harbored the Cereulide Synthetase gene. Moreover, eight haplotypes (Table 2) were identified. Overall, $24.72 \%$ of the strains harbored nhe $(A, B, C), h b l(A$, $C, D)$, cytK and entFM genes (haplotype H1). The haplotypes $\mathrm{H} 2$ (nhe $(A, B, C) ; h b l(A, C, D)$ ) and $\mathrm{H} 3$ (nhe $(A, B, C)$; cytK; entFM) were identified in $6.74 \%$ and $21.35 \%$ of isolates, respectively, while the haplotypes $\mathrm{H} 4$ (nhe $(A, B, C)$; entFM), $\mathrm{H} 5$ (nhe $(A, B, C)$; entFM; ces) and H6 (nhe $(A, C)$; hbl $(A, C, D)$; entFM) were identified in $35.95 \%, 1.12 \%$ and $5.62 \%$ of isolates, respectively.

\subsection{Exposure Assessment}

The average per capita consumption of cheese in Italy is $23 \mathrm{~kg}$ (ranging from $21.5 \mathrm{~kg}$ to $25 \mathrm{~kg}$ ) [33,34], with mozzarella accounting for about $15 \%$ of the total. The risk of exposure $\left(R_{x p}=\left(M_{C} / 100\right) \times R_{c}\right)$ was calculated on the basis of both the estimated average annual consumption of mozzarella $\left(\mathrm{M}_{\mathrm{C}}=3.5 \mathrm{~kg}\right.$ per capita $)$ and of the prevalence of contamination observed in the present study $\left(R_{c}=\right.$ Table 5). The estimated exposure risk varied according to the analytical method adopted (pathogen contamination, virulence profile and a combined approach based on both bacterial contamination and the virulence profile). If only bacterial contamination is considered, the exposure risk is "high", "moderate" and "low" for people whose annual consumption is around 50, 250 and $>600 \mathrm{~g}$ of mozzarella, respectively. (Figure 1). If only the molecular profile (toxinotyping) is considered, the exposure risk is "high", "moderate" and "low" for people whose annual consumption is around 200, 250 and $400 \mathrm{~g}$, 
respectively. On combining bacterial count and the virulence profile, the exposure risk is "high" and "moderate" for people whose annual consumption is around 100 and $200 \mathrm{~g}$, respectively.

Table 5. Number and percentage of water buffalo mozzarella cheese samples falling into the four risk categories (High, Moderate, Low, and No Risk) according to the methods of determination adopted (pathogen contamination, virulence profile and a combined approach based on both bacterial contamination and virulence profile).

\begin{tabular}{|c|c|c|c|c|}
\hline & \multicolumn{4}{|c|}{ Degree of Risk } \\
\hline & High & Moderate & Low & No Risk \\
\hline $\begin{array}{c}\text { B. cereus } \\
\text { contamination }\end{array}$ & $>5 \log \mathrm{CFU} / \mathrm{g}$ & $\begin{array}{c}>3 \log \text { to } \\
5 \log \text { CFU/g }\end{array}$ & $<3 \log \mathrm{CFU} / \mathrm{g}$ & No B. cereus isolate \\
\hline $\begin{array}{l}\text { No. mozzarella } \\
\text { samples }\end{array}$ & $6(1.8 \%)$ & $24(7.1 \%)$ & $59(17.3 \%)$ & $251(73.8 \%)$ \\
\hline $\begin{array}{l}\text { Virulence profile } \\
\text { of isolates }\end{array}$ & haplotype 1 & haplotypes 2 and 3 & haplotypes 4,5 and 6 & $\begin{array}{c}\text { Negative samples, } \\
\text { and isolates } \\
\text { without any } \\
\text { virulence } \\
\text { determinants }\end{array}$ \\
\hline $\begin{array}{l}\text { No. mozzarella } \\
\text { samples }\end{array}$ & $22(6.5 \%)$ & $25(7.3 \%)$ & $38(11.2 \%)$ & $255(75 \%)$ \\
\hline $\begin{array}{l}\text { Combination: } \\
\text { bacterial } \\
\text { contamination and } \\
\text { isolate virulotype }\end{array}$ & $\begin{array}{c}>3 \log \text { CFU/g and } \\
\text { haplotype } 1 \\
>5 \log \text { CFU/g and } \\
\text { haplotypes } 2 \text { and } 3\end{array}$ & $\begin{array}{c}<3 \log \text { CFU/g and } \\
\text { haplotype } 1 \\
\text { from } 3 \log \text { to } \\
5 \log \text { CFU/g and } \\
\text { haplotypes } 2 \text { and } 3\end{array}$ & $\begin{array}{c}>5 \log \text { and } \\
\text { haplotypes } 4,5 \text { and } 6\end{array}$ & $\begin{array}{l}\text { All remaining } \\
\text { conditions }\end{array}$ \\
\hline $\begin{array}{l}\text { No. mozzarella } \\
\text { samples }\end{array}$ & $12(3.5 \%)$ & $22(6.5 \%)$ & $0(0.0 \%)$ & $306(90.0 \%)$ \\
\hline
\end{tabular}

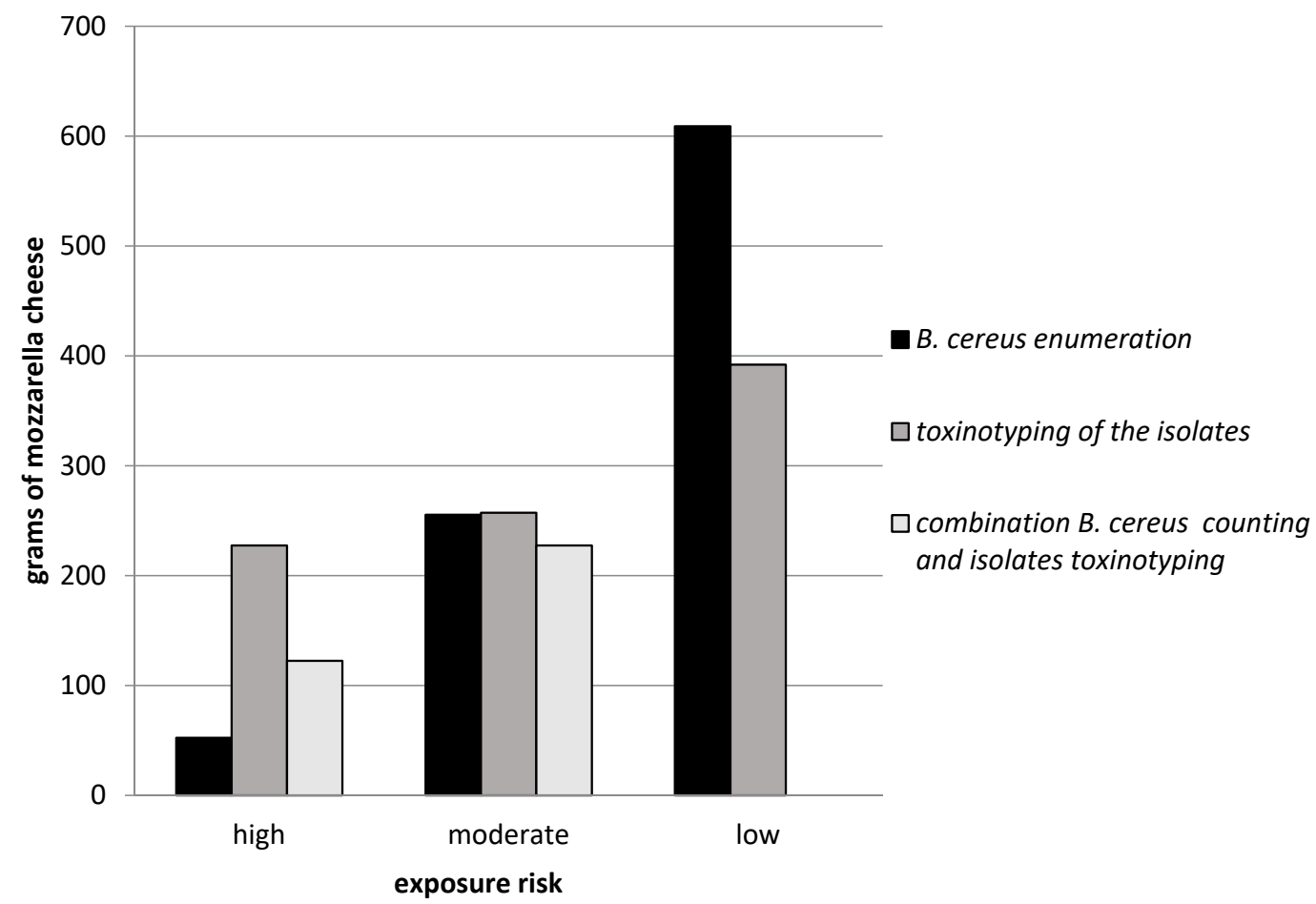

Figure 1. Annual amount of mozzarella consumed, subdivided by level of risk (high; moderate; low) and the method of risk determination (B. cereus counting; molecular profiling of isolates; combined evaluation: B. cereus counting plus molecular profiling of isolates). 


\section{Discussions}

In the present study, 89 samples were found to be contaminated by B. cereus, $6.74 \%$ of which showed levels of contamination considered to constitute a significant risk of poisoning ( $>5 \mathrm{Log}$ CFU/g) [16] (Table 2) already at the moment of purchase. To our knowledge, this is the first study to provide data on the prevalence of $B$. cereus in WBMC. The presence of this pathogen in these samples may be due either to the germination of spores present in raw milk which were not suppressed during the phase of curd stretching, or to the survival of the pathogen due to protection by the protein matrix and fat content and/or to an uneven distribution of heat during the curd-stretching process [25].

Regarding the risk of poisoning, storage conditions at home may also have a heavy impact. Indeed, our estimates of the growth rate of $B$. cereus in WBMC samples with an initial contamination of 2 or $3 \log \mathrm{CFU} / \mathrm{g}$ under the conditions considered $\left(15,18,22^{\circ} \mathrm{C}\right)$ revealed that the pathogen can reach risk levels ( $\geq 5 \log \mathrm{CFU} / \mathrm{g}$ ) in 21 to $63 \mathrm{~h}$ (Table 3). Storage conditions, in terms of temperature and time, as commonly indicated by producers, may differ considerably; however, in the geographical area of production, WBMC is usually stored at room temperature and eaten within a few days after its production. To simulate these storage conditions, we considered three temperatures $\left(15,18\right.$ and $\left.22{ }^{\circ} \mathrm{C}\right)$ in our analysis. The short shelf life of mozzarella contributes to reducing the risk, although appropriate storage temperatures must be ensured, especially in summer. Indeed, at the storage temperature of $22^{\circ} \mathrm{C}$, contaminated samples can reach a risk condition $(>5 \log \mathrm{CFU} / \mathrm{g}$ ) in approximately $24 \mathrm{~h}$ (Table 3). The increase in bacterial load during storage spoils the cheese, thereby reducing the risk to health. By contrast, in dairy products that show a high level of contamination from the outset, significant alterations do not occur; in these products, the risk is potentially greater.

The EU Commission's definition of exposure assessment is “... estimation of how likely it is that an individual or a population will be exposed to a microbial hazard and what numbers of micro-organisms are likely to be ingested" [35]. However, the assumption that the risk depends basically on the level of microbial contamination does not consider the various molecular profiles of $B$. cereus isolates. Indeed, $B$. cereus is potentially able to synthesize several toxins, but most of the bacteria belonging to this group lack toxin-producing genes. To assess risk correctly, it is therefore crucial to evaluate the molecular profile (toxinotype) of the isolates, rather than simply counting the bacteria [11]. In the present study, the presence of nine genes encoding toxins was evaluated in the strains isolated. The analysis of the isolates showed that not all of them were positive for all the genes tested for. However, most of the isolates analyzed in our study harbored one or more genes involved in the production of toxins (Table 2).

In the present study, the isolates were classified into hazard categories according to their molecular profile (Table 5). On the basis of the genes harbored, six haplotypes (H1-H6) showed virulence properties related to possible food-borne poisoning, as reported by [36]. Based on the presence or absence of the different genes recognized as playing a major role in the disease, we have categorized the haplotypes in three groups on the basis of the risk for B. cereus disease: haplotypes at "high risk", "moderate risk" and "low risk". The haplotype $\mathrm{H} 1$ harboring nhe $(A, B, C), h b l(A, C, D)$, cytK and entFM genes has been considered the haplotype as having the greatest risk ("High Risk") to cause enteric disorders.

Isolates characterized by the haplotypes $\mathrm{H} 2(n h e(A, B, C) ; h b l(A, C, D))$ and $\mathrm{H} 3($ nhe $(A, B, C)$; cytK; entFM) showed a "Moderate Risk" owing to the presence of the nhe and hbl genes in $\mathrm{H} 2$ and the presence of $n h e$ and $c y t K$ genes in H3. However, compared with H1, the risk of enteric disorders arising from the consumption of foods contaminated with $\mathrm{H} 2$ and $\mathrm{H} 3$ is lower for the absence of $c y t K$ gene, which toxin is highly toxic towards human intestinal epithelial cells [37], or $h b l$ genes. Indeed, HBL complex is one of the most important responsible for enterotoxigenic activity of B. cereus strains, thus its absence leads to a reduction in the cytotoxic and hemolytic activity of this pathogen $[38,39]$. Haplotypes H4 (nhe $(A, B, C)$; entFM), H5 (nhe $(A, B, C)$; entFM; ces) and H6 (nhe $(A, C)$; hbl $(A, C, D)$; entFM) showed a lower level of risk ("Low Risk"), owing to the absence in all of them of the cytK gene and the additional absence of genes coding for HBL toxin components or of the nheB gene. H6, 
which was infrequently detected (5.6\%), harbored the incomplete nhe operon; it was therefore regarded as posing a low risk, because all three components (A, B and C) of the nhe operon are needed for full toxicity [11]. The ces gene was detected in only one B. cereus isolate, jointly with the complete nhe operon and entFM gene (haplotype 5). As reported in Table 5, considering the virulence profile alone, $22(6.5 \%), 25(7.3 \%)$ and $38(11.2 \%)$ of the B. cereus isolates analyzed showed a profile of high, moderate, and low risk, respectively.

However, risk cannot be reliably assessed by considering the molecular profile and the bacterial count separately [11]. In the present study, risk was assessed by jointly evaluating the results of microbiological and molecular assays. In this analysis, the "high risk" category comprised samples with $B$. cereus contamination above $10^{3} \mathrm{CFU} / \mathrm{g}$ - an infective dose considered unsafe for human consumption [40] -and high-risk toxinotype strains (haplotype 1), and those with higher B. cereus contamination $\left(>10^{5} \mathrm{CFU} / \mathrm{g}\right.$ ) but lower molecular risk profiles of the isolates (haplotypes 2 and 3). The "moderate risk" group comprised samples displaying a higher risk of toxic strains (haplotype 1) but lower bacterial contamination, and samples with an intermediate level of contamination (from 3 to $5 \log$ CFU/g) and haplotypes 2 and 3. All the remaining samples were classified as "no risk", as shown in Table 5.

According to the above risk classification, most of the samples showed no risk (90.0\%). By contrast, bacterial counting and the molecular approach assigned fewer samples to this group $(73.8 \%$ and $75 \%$, respectively).

However, in the present study, the occurrence of the toxins in WBMC was not evaluated. Unlike the diarrheal form caused by the enterotoxins that are produced in the intestine, the emetic syndrome is associated with the presence of the toxin cereulide pre-formed in foods [11]. Thus, for a complete virulence assessment, the detection of the toxin cereulide should be also included.

The response of consumers to exposure to B. cereus is highly variable and depends on many factors, including the virulence profile of the pathogen, the numbers of cells ingested as spores or as vegetative cells [41], the general health status of the host, and the host's gut microbiome. If the risk of exposure were estimated only on the basis of the intensity of exposure, all these aspects would have little impact on the assessment. Moreover, to appraise risk, data on mozzarella consumption by different subpopulations should be included in the analysis; unfortunately, however, little information on the typology of mozzarella consumers is available.

On the basis of the results of the present study, given that a standard portion of mozzarella is of about $100 \mathrm{~g}$, the annual risk of exposure is assessed as being from 0.5 to 2.9 portions at high risk, from 2.5 to 3.9 portions at moderate risk and from 0.5 to 6 portions at low risk. Overall, analysis of the toxin profile alone leads to an overestimation of the risk, while evaluations based on the $B$. cereus count and the combined assessments of the count and the toxinotype provide more homogeneous results; this latter approach can explain the reported cases of poisoning associated with the consumption of foods with low levels of $B$. cereus contamination [17]. According to this approach, in order to engender a high risk of poisoning, the total number of $B$. cereus cells should be between $10^{5} / \mathrm{CFU} \times 100 \mathrm{~g}$ and $>10^{7} / \mathrm{CFU} \times 100 \mathrm{~g}$, depending on the characteristics of the microorganisms.

\section{Conclusions}

In conclusion, the consumer runs a moderate risk of buying water buffalo mozzarella cheese with a level of B. cereus high enough to cause food poisoning. However, the results of the present study showed that the risk of poisoning may increase during storage at room temperature, because the pathogen is able to grow rapidly. Moreover, a high percentage of the strains isolated harbored genes involved in toxin production, and a high percentage showed virulence properties associated with possible food-borne poisoning. However, on combining the findings of bacterial counting and analysis of the molecular profile, a different level of risk emerged. Specifically, a lower number of samples proved to be at high or moderate toxic risk. Furthermore, if the average per capita consumption of water buffalo mozzarella cheese is considered, the risk of poisoning by B. cereus is even lower. 
Only a combined approach based on the B. cereus count and the molecular profiles of isolates can accurately assess the risk of poisoning. However, for a more complete evaluation, data on the typology of mozzarella consumers and the impact of $B$. cereus poisoning on human beings would be necessary. Indeed, the present study lacks quantitative information on the consequences of exposure. This is because the surveillance of enteric disorders in human beings is in some cases inadequate, especially with regard to self-limiting disorders, such as those caused by B. cereus. Moreover, additional research is clearly needed in order to investigate the occurrence of the toxins in the water buffalo mozzarella cheese for a deep evaluation of the health risk originating from the consumption of this food.

Supplementary Materials: The following are available online at http://www.mdpi.com/2304-8158/9/12/1899/s1, Table S1: B. cereus's maximum growth rate (log.conc/h), double time (hours), maximum population density (MPD; $\log$ CFU/g) and lag time (hours) estimated through ComBase predictor software (www.combase.cc) from an initial contamination level of $2 \mathrm{Log}$ CFU/g and $3 \mathrm{Log}$ CFU/g in water buffalo mozzarella cheese (with a pH 5.7 and an $\mathrm{a}_{\mathrm{w}}$ $0.997)$ at three temperature $\left(15,18\right.$ and $\left.22^{\circ} \mathrm{C}\right)$.

Author Contributions: Conceptualization, D.C., F.C. and Y.T.R.P.; methodology, A.M.I.M.; software, A.M.; validation, O.D.M., A.M. and D.C.; formal analysis, A.M.I.M.; investigation, D.C.; resources, O.D.M.; data handling, F.C. and A.M.; writing-original draft preparation, A.M.I.M. and M.F.P.; writing-review and editing, M.F.P. and F.C.; visualization, M.F.P.; supervision, F.C.; project administration, Y.T.R.P. and F.C. All authors have read and agreed to the published version of the manuscript.

Funding: This research did not receive any specific grant from funding agencies in the public, commercial, or not-for-profit sectors.

Acknowledgments: The authors wish to thank the CRIPAT-PAT (Regional Reference Center for the Safety of Traditional Agri-Food Productions) of the Campania Region for helping to find national data on cheese and mozzarella.

Conflicts of Interest: The authors declare no potential conflicts of interest.

\section{References}

1. Fayad, N.; Kallassy Awad, M.; Mahillon, J. Diversity of Bacillus cereus sensu lato mobilome. BMC Genom. 2019, 20, 1-11. [CrossRef] [PubMed]

2. Guinebretière, M.H.; Auger, S.; Galleron, N.; Contzen, M.; de Sarrau, B.; de Buyser, M.L.; Lamberet, G.; Fagerlund, A.; Granum, P.E.; Lereclus, D.; et al. Bacillus cytotoxicus sp. nov. is a novel thermotolerant species of the Bacillus cereus group occasionally associated with food poisoning. Int. J. Syst. Evol. Microbiol. 2013, 63, 31-40. [CrossRef] [PubMed]

3. Lapidus, A.; Goltsman, E.; Auger, S.; Galleron, N.; Ségurens, B.; Dossat, C.; Land, M.L.; Broussolle, V.; Brillard, J.; Guinebretiere, M.H.; et al. Extending the Bacillus cereus group genomics to putative food-borne pathogens of different toxicity. Chem. Biol. Interact. 2008, 171, 236-249. [CrossRef] [PubMed]

4. Oren, A.; Garrity, G.M. List of new names and new combinations previously effectively, but not validly, published. Int. J. Syst. Evol. Microbiol. 2016, 66, 2463-2466. [CrossRef]

5. Heini, N.; Stephan, R.; Ehling-Schulz, M.; Johler, S. Characterization of Bacillus cereus group isolates from powdered food products. Int. J. Food Microbiol. 2018, 283, 59-64. [CrossRef]

6. Ehling-Schulz, M.; Lereclus, D.; Koehler, T.M. The Bacillus cereus Group: Bacillus Species with Pathogenic Potential. Microbiol. Spectr. 2019, 7. [CrossRef]

7. Lund, T.; Granum, P.E. Comparison of biological effect of the two different enterotoxin complexes isolated from three different strains of Bacillus cereus. Microbiology 1997, 143, 3329-3336. [CrossRef]

8. Schoeni, J.L.; Lee Wong, A.C. Bacillus cereus food poisoning and its toxins. J. Food Prot. 2005, 68, 636-648. [CrossRef]

9. Stenfors Arnesen, L.P.; Fagerlund, A.; Granum, P.E. From soil to gut: Bacillus cereus and its food poisoning toxins. FEMS Microbiol. Rev. 2008, 32, 579-606. [CrossRef]

10. Tran, S.L.; Guillemet, E.; Gohar, M.; Lereclus, D.; Ramarao, N. CwpFM (EntFM) is a Bacillus cereus potential cell wall peptidase implicated in adhesion, biofilm formation, and virulence. J. Bacteriol. 2010, 192, 2638-2642. [CrossRef] 
11. Jessberger, N.; Kranzler, M.; Da Riol, C.; Schwenk, V.; Buchacher, T.; Dietrich, R.; Ehling-Schulz, M.; Märtlbauer, E. Assessing the toxic potential of enteropathogenic Bacillus cereus. Food Microbiol. 2019, 84, 103276. [CrossRef] [PubMed]

12. Ramarao, N.; Tran, S.L.; Marin, M.; Vidic, J. Advanced methods for detection of Bacillus cereus and its pathogenic factors. Sensors 2020, 20, 2667. [CrossRef] [PubMed]

13. Molva, C.; Sudagidan, M.; Okuklu, B. Extracellular enzyme production and enterotoxigenic gene profiles of Bacillus cereus and Bacillus thuringiensis strains isolated from cheese in Turkey. Food Control 2009, 20, 829-834. [CrossRef]

14. Van der Auwera, G.A.; Timmery, S.; Hoton, F.; Mahillon, J. Plasmid exchanges among members of the Bacillus cereus group in foodstuffs. Int. J. Food Microbiol. 2007, 113, 164-172. [CrossRef]

15. Webb, M.D.; Barker, G.C.; Goodburn, K.E.; Peck, M.W. Risk presented to minimally processed chilled foods by psychrotrophic Bacillus cereus. Trends Food Sci. Technol. 2019, 93, 94-105. [CrossRef]

16. EFSA. Opinion of the Scientific Panel on biological hazards (BIOHAZ) on Bacillus cereus and other Bacillus spp. in foodstuffs. EFSA J. 2005, 3, 175. [CrossRef]

17. EFSA. Risks for public health related to the presence of Bacillus cereus and other Bacillus spp. including Bacillus thuringiensis in foodstuffs-EFSA Panel on Biological Hazards (BIOHAZ). EFSA J. 2016, 14, 4524. [CrossRef]

18. EFSA (European Food Safety Authority); ECDC (European Centre for Disease Prevention and Control). The European Union Summary Report on Trends and Sources of Zoonoses, Zoonotic Agents and Food-borne Outbreaks in 2011. EFSA J. 2013, 11, 3129. [CrossRef]

19. Martinelli, D.; Fortunato, F.; Tafuri, S.; Cozza, V.; Chironna, M.; Germinario, C.; Pedalin, B.; Prato, R. Lessons learnt from a birthday party: A Bacillus cereus outbreak, Bari, Italy, January 2012. Ann. dell'Istituto Super. Sanità 2013, 49, 391-394. [CrossRef]

20. Zicari, G.; Gorrasi, I.; Di Gioia, S.; Rossi, M.V.; Traversi, D.; Rivetti, D.; Soardo, V.; Cerrato, E.; Carraro, E.; Gilli, G.; et al. Foodborne outbreaks surveillance in the Piedmont Region, Italy (2002-2009). Ig. Sanità Pubblica 2011, 67, 721-742.

21. Ombui, J.N.; Gitahi, J.N.; Gicheru, M.M. Direct detection of bacillus cereus enterotoxin genes in food by multiplex polymerase chain reaction. Int. J. Integr. Biol. 2008, 2, 172-181.

22. EFSA (European Food Safety Authority); ECDC (European Centre for Disease Prevention and Control). The European Union Summary Report on Trends and Sources of Zoonoses, Zoonotic Agents and Food-borne Outbreaks in 2012. EFSA J. 2014, 12, 312. [CrossRef]

23. Bonerba, E.; Di Pinto, A.; Novello, L.; Montemurro, F.; Terio, V.; Colao, V.; Ciccarese, G.; Tantillo, G. Detection of potentially enterotoxigenic food-related Bacillus cereus by PCR analysis. Int. J. Food Sci. Technol. 2010, 45, 1310-1315. [CrossRef]

24. Aponte, M.; Pepe, O.; Blaiotta, G. Short communication: Identification and technological characterization of yeast strains isolated from samples of water buffalo Mozzarella cheese. J. Dairy Sci. 2010, 93, 2358-2361. [CrossRef] [PubMed]

25. Murru, N.; Peruzy, M.F.; De Carlo, E.; Mercogliano, R.; Aponte, M.; Morena, C.; Serluca, G.; Fraulo, P. Listeria monocytogenes survival during production and storage of water buffalo Mozzarella cheese. Int. J. Dairy Technol. 2018, 71, 356-361. [CrossRef]

26. Serraino, A.; Finazzi, G.; Marchetti, G.; Daminelli, P.; Riu, R.; Giacometti, F.; Losio, M.N.; Rosmini, R. Behaviour of Salmonella Typhimurium during production and storage of artisan water buffalo mozzarella cheese. Ital. J. Anim. Sci. 2012, 11, 285-289. [CrossRef]

27. De Santis, E.P.L.; Foddai, A.; Virdis, S.; Marongiu, P.; Pilo, A.L.; Scarano, C. Toxin gene pattern in Bacillus cereus group strains isolated from sheep ricotta cheese. Vet. Res. Commun. 2008, 32, 323-326. [CrossRef]

28. Berthold-Pluta, P.; Garbowska, S. Prevalence and toxicity characterization of Bacillus cereus in food products from Poland. Foods 2019, 8, 269. [CrossRef]

29. Rea, S.; Marino, L.; Stocchi, R.; Branciari, R.; Loschi, A.R.; Miraglia, D.; Ranucci, D. Differences in chemical, physical and microbiological characteristics of Italian Burrata cheeses made in artisanal and industrial plants of the Apulia Region. Ital. J. Food Saf. 2016, 5. [CrossRef]

30. Nava, D.; Capo, S.; Caligiuri, V.; Giaccone, V.; Biondi, L.; Vaccaro, G.F.; Guarino, A.; Capuano, F. Study of the population dynamics of Listeria monocytogenes and pseudomonas fluorescens in buffalo-milk mozzarella cheese by means of challenge testing. Ital. J. Food Saf. 2016, 5, 2-4. [CrossRef] 
31. Ngamwongsatit, P.; Buasri, W.; Pianariyanon, P.; Pulsrikarn, C.; Ohba, M.; Assavanig, A.; Panbangred, W. Broad distribution of enterotoxin genes (hblCDA, nheABC, cytK, and entFM) among Bacillus thuringiensis and Bacillus cereus as shown by novel primers. Int. J. Food Microbiol. 2008, 121, 352-356. [CrossRef] [PubMed]

32. Ehling-Schulz, M.; Frenzel, E.; Gohar, M. Food-bacteria interplay: Pathometabolism of emetic Bacillus cereus. Front. Microbiol. 2015, 6, 1-12. [CrossRef] [PubMed]

33. Wielicka, A.; Gorynska-Goldmann, E. World and Poland Per Capita Cheese Consumption. Rocz. Akad. Rol. Pozaniu 2005, 4, 157-166.

34. Global Mozzarella Cheese Market 2020 by Manufacturers, Regions, Type and Application, Forecast to 2025. Available online: https://www.bharatbook.com/marketreports/global-mozzarella-cheese-market-2019-bymanufacturers-regions-type-and-application-forecast-to-2024/1409689 (accessed on 15 July 2020).

35. Lammerding, A.; Fazil, A. Hazard identification and exposure assessment for microbial food safety risk assessment, in Food Microbiology and Food Safety into the next Millennium. Int. Comm. Food Microbiol. 2000, 58, 433-437. [CrossRef]

36. Guinebretière, M.H.; Broussolle, V.; Nguyen-The, C. Enterotoxigenic profiles of food-poisoning and food-borne Bacillus cereus strains. J. Clin. Microbiol. 2002, 40, 3053-3056. [CrossRef] [PubMed]

37. Fagerlund, A.; Ween, O.; Lund, T.; Hardy, S.P.; Granum, P.E. Genetic and functional analysis of the cytK family of genes in Bacillus cereus. Microbiology 2004, 150, 2689-2697. [CrossRef] [PubMed]

38. Lindbäck, T.; Økstad, O.A.; Rishovd, A.L.; Kolstø, A.B. Insertional inactivation of hblC encoding the L2 component of Bacillus cereus ATCC 14579 haemolysin BL strongly reduces enterotoxigenic activity, but not the haemolytic activity against human erythrocytes. Microbiology 1999, 145, 3139-3146. [CrossRef]

39. Amor, M.G.B.; Jan, S.; Baron, F.; Grosset, N.; Culot, A.; Gdoura, R.; Gautier, M.; Techer, C. Toxigenic potential and antimicrobial susceptibility of Bacillus cereus group bacteria isolated from Tunisian foodstuffs. BMC Microbiol. 2019, 19, 196.

40. Granum, P.E.; Lund, T. Bacillus cereus and its food poisoning toxins. FEMS Microbiol. Lett. 1997, 157, $223-228$. [CrossRef]

41. Ceuppens, S.; Uyttendaele, M.; Hamelink, S.; Boon, N.; Van De Wiele, T. Inactivation of Bacillus cereus vegetative cells by gastric acid and bile during in vitro gastrointestinal transit. Gut Pathog. 2012, 4, 5-11. [CrossRef]

Publisher's Note: MDPI stays neutral with regard to jurisdictional claims in published maps and institutional affiliations.

(C) 2020 by the authors. Licensee MDPI, Basel, Switzerland. This article is an open access article distributed under the terms and conditions of the Creative Commons Attribution (CC BY) license (http://creativecommons.org/licenses/by/4.0/). 